\title{
MINERAL RESOURCE POTENTIAL OF THE GREAT RIFT INSTANT STUDY AREA BLAINE, BUTTE, MINIDOKA, AND POWER COUNTIES, IDAHO
}

\author{
By \\ James Ridenour and Ronald B. Stotelmeyer, U. S. Bureau of Mines \\ and \\ Mel A. Kuntz, Don R. Mabey, Duane E. Champion, Richard H. Lefebvre, \\ and W. D. Stanley, U. S. Geological Survey
}

\author{
STUDIES RELATED TO WILDERNESS \\ Bureau of Land Management Wilderness Study Areas
}

The Federal Land Policy and Management Act (Public Law 94-579, October 21, 1976) requires the U.S. Geological Survey and the U.S. Bureau of Mines to conduct mineral surveys on certain areas to determine their mineral resource potential. Results must be made available to the public and be submitted to the President and the Congress. This report presents the results of a mineral survey of the Great Rift Instant Study Area, Blaine, Butte, Minidoka, and Power Counties, Idaho.

\section{MINERAL RESOURCE POTENTIAL SUMMARY STATEMENT}

A high potential exists for development of decorative building stone resources from slabby, glassy-surfaced pahoehoe lava flows, particularly in the Wapi lava field where the largest volume and variety of stone occurs. The unique appearance of the Blue Dragon flow material from the Craters of the Moon lava field may enhance its potential as a decorative stone resource.

Locating speculative resources (uraniferous sediment, auriferous gravel, and geothermal reservoirs) and hypothetical resources (oil and gas) that may underlie the geologically young lava flows of the study area would require extensive geophysical exploration and drilling.

\section{INTRODUCTION}

The Great Rift Instant Study Area is located in the Snake River Plain of south central Idaho. The study area consists of two parts, a northern part comprising 287,800 acres $\left(1,165 \mathrm{~km}^{2}\right)$ partly surrounding the Craters of the Moon National Monument, and a southern part comprising 86,600 acres $\left(350 \mathrm{~km}^{2}\right.$ ) (fig. 1). Both parts encompass young, fresh basaltic lava flows that have been erupted from fissure-controlled vents along the Great Rift.

The study area ranges in elevation from about $4,400 \mathrm{ft}(1,340 \mathrm{~m})$ to about $5,750 \mathrm{ft}(1,750 \mathrm{~m})$ and is relatively flat, except in local areas near cinder cones and steep lava flow fronts. The young lava flows and their vent areas have hummocky, blocky, and cindery surfaces that are almost completely free of soil and vegetation. There are no roads in the study area and it is currently free of any commercial or agricultural development.

\section{GEOLOGY}

The Great Rift is a volcanic rift zone, a set of volcanic vents, eruptive fissures, and noneruptive fissures (Prinz, 1970). The Great Rift extends about $55 \mathrm{mi}(85 \mathrm{~km})$ from the southern Pioneer Mountains southeastward through Craters of the Moon National Monument and the northern part of the study area to
Pillar Butte, located about $20 \mathrm{mi}(30 \mathrm{~km})$ northwest of American Falls, in the southern part of the study area. Three Holocene and latest Pleistocene lava fields are alined along the Great Rift. The Craters of the Moon lava field covers an area of about $600 \mathrm{mi}^{2}(1600$ $\mathrm{km}^{2}$ ) and consists of more than 40 lava flows that were erupted from more than 25 cinder cones and eight eruptive fissures. Most of these vents are located within the Craters of the Moon National Monument but some extend into the northern part of the study area. The northern part of the study area includes a large part of the Craters of the Moon lava field that is not included in the Craters of the Moon National Monument. The Kings Bowl lava field is made up of lava flows of limited extent $\left(1.3 \mathrm{mi}^{2}, 3.2 \mathrm{~km}^{2}\right)$ that were erupted from fissure vents in the southern part of the Great Rift. The Kings Bowl lava field is not included in the Great Rift Instant Study Area. The Wapi lava field is a broad shield volcano that covers an area of about $120 \mathrm{mi}^{2}(310 \mathrm{~km})$; its vent complex constitutes Pillar Butte. The southern part of the study area covers nearly all of the Wapi lava field.

All three lava fields consist of mostly fresh, largely unweathered pahoehoe and a'a lava flows. The Craters of the Moon Lava field formed during eight eruptive periods, each less than 1,000 years long and separated from one another by intervals that were several hundred to as much as several thousand years long. The first eruptive period began about 15,000 


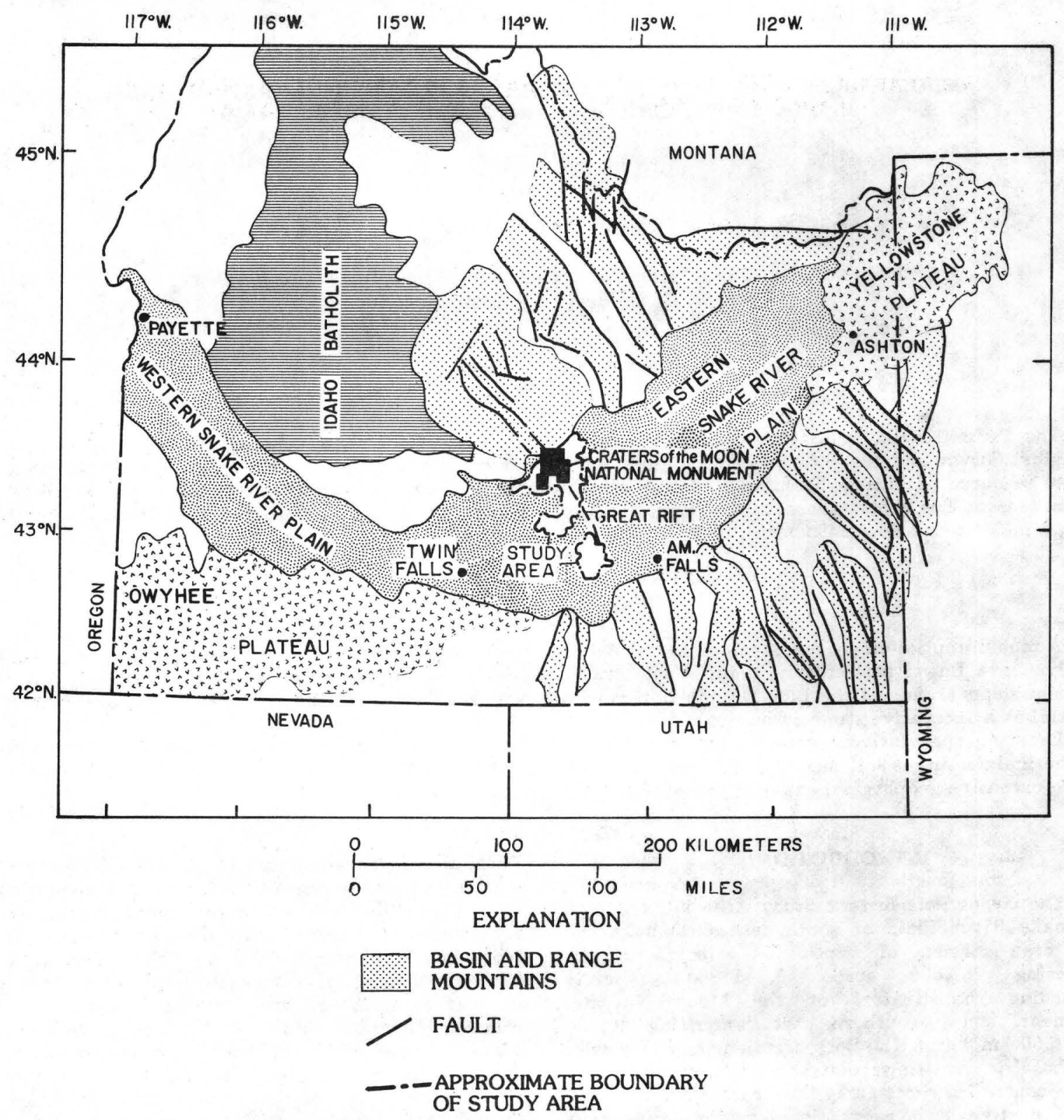

Figure 1.--Index map showing the location of the Great Rift Instant Study Area. 
years ago and the last eruptive period occurred about 2,100 years ago. The Kings Bowl and Wapi lava fields both were formed during short, probably simultaneous eruptions along separate segments of the southern part of the Great Rift about 2,200 years ago.

The lava flows of the three lava fields are dark colored and dense in hand specimen; they have fresh, nearly unweathered crusts; and they are largely free of soil and vegetation. Cones formed at point sources on fissures consist of cinders, blocks, bombs, lapilli, and ash, some of which is locally agglutinated. Eruptive fissures are bordered by spatter ramparts.

\section{GEOPHYSICS}

Magnetic anomalies in the study area are complex and reflect 3 primary factors: (1) local surface relief, (2) direction of magnetization, and (3) thickness and depth of sequences of flows with normal or reverse magnetization. The magnetic field also reflects magnetic masses underlying and within the basalt flows, including intrusive basalt, volcanic rocks older than the basalt flows, large silicic intrusives, and perhaps a magnetic basement complex. A magnetic high centered beneath the Craters of the Moon National Monument and the northern part of the study area is interpreted to reflect a deep-seated intrusive body that is related to a northwest-trending structure that lies parallel to the Great Rift and extends northwest beyond the limits of the Snake River Plain. Magnetic data suggest that the northern part of the study area may reflect anomalously high temperatures in the crust.

A broad geavity low is roughly coincident with the magnetic high in the Craters of the Moon area; both anomalies could be produced by a silicic intrusive body. A magnetotelluric investigation of the study area reveals a four-part upper crustal region that consists of four layers of varying resistivity. From the surface to a depth of about $12 \mathrm{mi}(20 \mathrm{~km})$, the four layers are believed to represent basaltic lava flows, rhyolitic lava flows, basement rocks of high resistivity, and basement rocks of low resistivity (Kuntz and others, 1983).

\section{ASSESSMENT OF MINERAL RESOURCE POTENTIAL}

No mining districts exist in either the northern or southern parts of the Great Rift Instant Study Area. No mining claims have been filed in the northern part of the study area, but a group of eight claims, presumably for building stone, was located at Pillar Butte in 1980.

Identified resources in the study area are confined mainly to decorative building stone and volcanic cinders (figs. 2 and 3 ). Decorative building stone consists chiefly of slabs of pahoehoe lava, 1-4 in. (2.5-10 cm ) thick, that occur at the margins of flows and flow units, near vent rims, and in squeeze-ups. Resources of building stone in the northern part of the study area are about 5,500 tons $(5,400 \mathrm{t})$, and 10,000 tons $(9,100 t)$ are inferred. Inferred surface resources of useable building stone in the southern part of the study area may approach a half million tons. Volcanic cinders for use as road metal, fill, and so on, are found in cinder cones along the Great Rift, mainly in the northern part of the study area.

Speculative resources of geothermal water, auriferous gravel, uraniferous silt, and hypothetical reservoirs of oil and gas that may lie within and beneath the basaltic lava flows of the study area may be inferred on the basis of occurrences largely outside the study area. Locating such resources would require extensive geophysical exploration and drilling.

\section{RFFERENCES CITED}

Kuntz, M. A., Mabey, D. R., Champion, D. E., Stanley, W. D., Lefebvre, R. H., Spiker, E. C., McBroome, L. A., and Covington, H. R., 1983, Geologic and geophysical maps of the Great Rift Instant Study Area, Blaine, Butte, Minidoka, and Power Counties, Idaho: U.S. Geological Survey, MF1462-A.

Prinz, M., 1970, Idaho rift system, Snake River Plain, Idaho: Geological Society of America Bulletin, v. 81, no. 3, p. 941-947. 


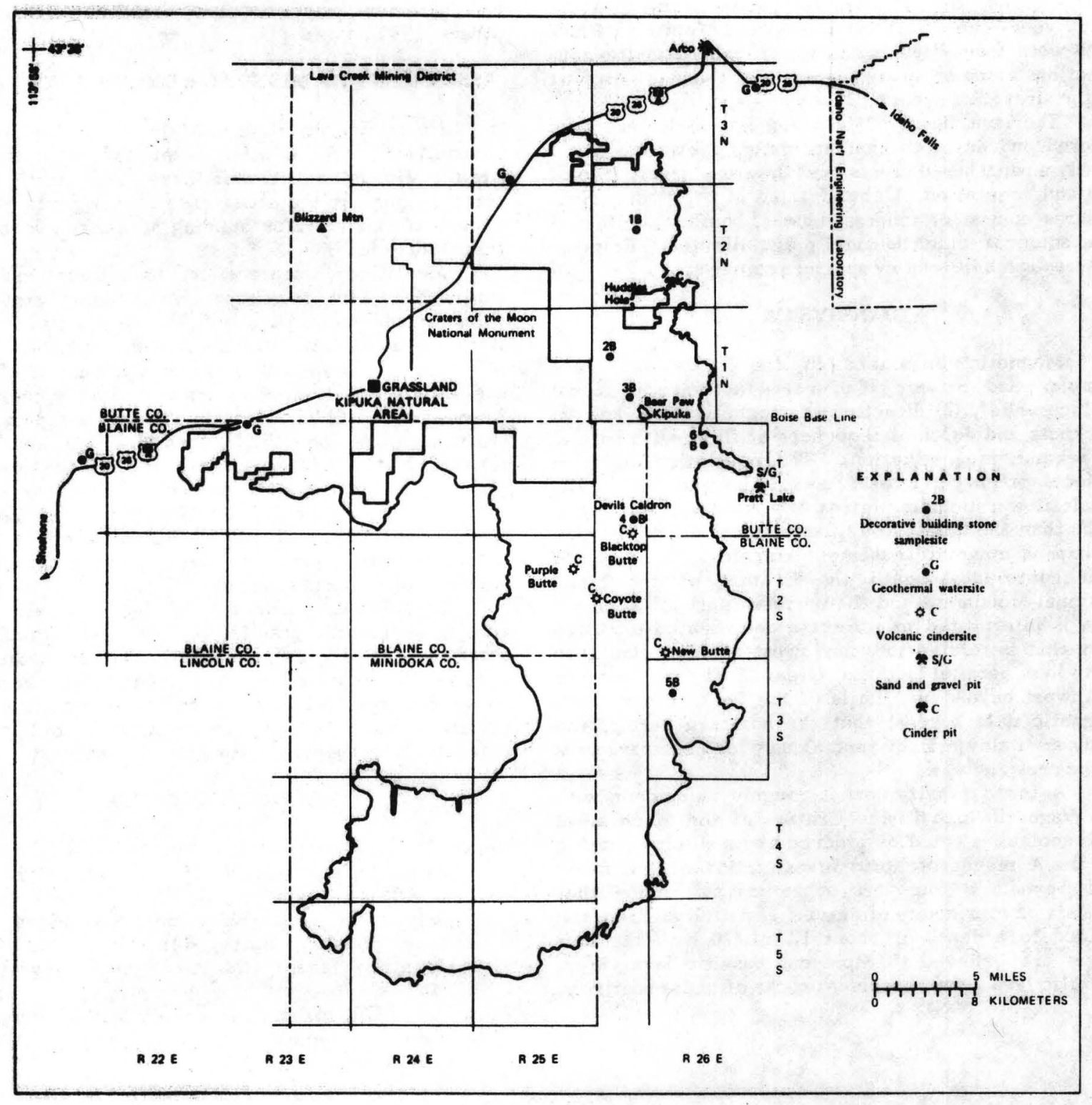

Figure 2.-Mineral resource potential map showing the location of resources in the northern part of the Great Rift Instant Study Area. 


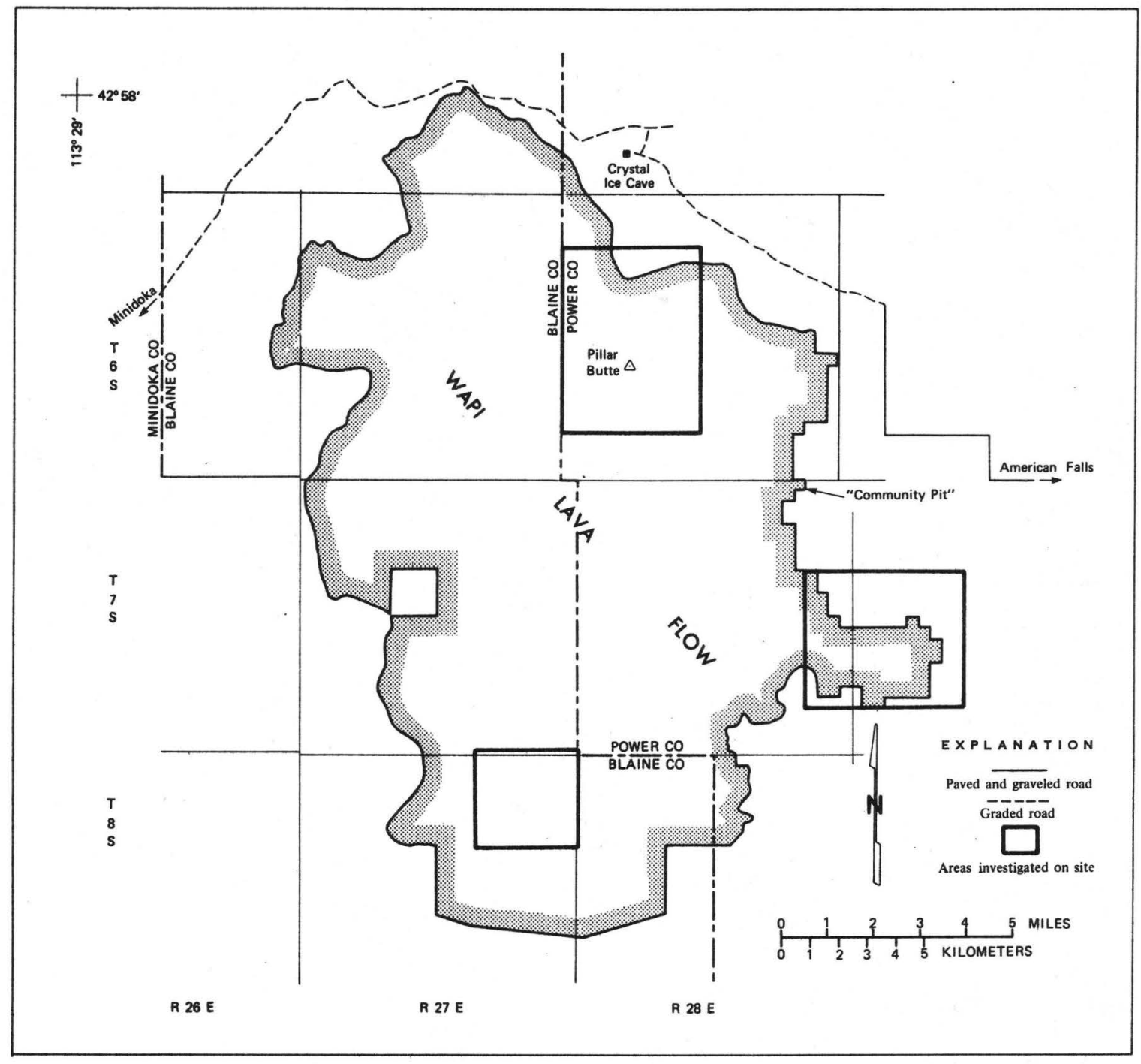

Figure 3.--Mineral resource potential map showing sites investigated for decorative building stone in the southern part of the Great Rift Instant Study Area. 